\title{
Tax Shelters or Efficient Tax Planning? A Theory of the Firm Perspective on the Economic Substance Doctrine
}

\section{Citation}

Borek, Christopher T, Angelo Frattarelli, and Oliver Hart. 2014. Tax Shelters or Efficient Tax Planning? A Theory of The Firm Perspective On the Economic Substance Doctrine. Journal of Law and Economics 57, no. 4: 975-1000

\section{Published Version}

doi:10.1086/680929

\section{Permanent link}

http://nrs.harvard.edu/urn-3:HUL.InstRepos:30703804

\section{Terms of Use}

This article was downloaded from Harvard University's DASH repository, and is made available under the terms and conditions applicable to Other Posted Material, as set forth at http:// nrs.harvard.edu/urn-3:HUL.InstRepos:dash.current.terms-of-use\#LAA

\section{Share Your Story}

The Harvard community has made this article openly available.

Please share how this access benefits you. Submit a story.

\section{Accessibility}




\title{
Tax Shelters or Efficient Tax Planning? A Theory of the Firm Perspective on the Economic Substance Doctrine
}

\author{
T. Christopher Borek Analysis Group \\ Angelo Frattarelli U.S. Department of Justice \\ Oliver Hart Harvard University
}

\begin{abstract}
Courts have articulated a number of legal tests to distinguish corporate transactions that have a legitimate business or economic purpose from those carried out largely, if not solely, for favorable tax treatment. We outline an approach to analyzing the economic substance of corporate transactions based on the property rights theory of the firm and describe its application in two recent tax cases.
\end{abstract}

\section{Introduction}

Litigation has long revealed difficulties in designing, implementing, and interpreting tax law in a manner that allows taxpayers to claim intended benefits without encouraging abuse. To evaluate the tax consequences of a business transaction, one must first determine whether it satisfies the relevant provisions of the Internal Revenue Code. But, recognizing that taxpayers sometimes engage in transactions to reduce their taxes in ways beyond what the tax code intends, the Supreme Court long ago empowered federal courts to ask "whether what was done, apart from the tax motive, was the thing which the statute intended" (Gregory v. Helvering, 293 U.S. 465, 469 [1935]). Federal courts, following the Supreme

Hart served as a testifying expert and Borek provided research support on behalf of the United States in WFC Holdings Corp. v. United States (2011 WL 4583817 [D. Minn. 2011], aff'd 728 F.3d 736 [8th Cir. 2013]) and Black \& Decker Corp. v. United States (340 F. Supp. 2d [D. Md. 2004], affd in part, rev'd and remanded in part, 436 F.3d 431 [4th Cir. 2006]). Frattarelli was lead trial counsel for the United States in Black \& Decker. The views expressed are the authors' and do not represent the official position of the Tax Division, the Department of Justice, or any other government agency. We thank Jennifer Arlen, Karen Burke, Gabriel Cappelli, Louis Kaplow, Geoffrey Miller, Andrei Shleifer, participants at the 2014 Harvard Law School Seminar on Current Issues in Tax Law, Policy and Practice, participants at the 2014 New York University Law School colloquium on law and economics, participants at the 2014 Tinbergen Institute seminar in Amsterdam, the referee, and an editor for helpful comments. Hart gratefully acknowledges financial support from the U.S. National Science Foundation through the National Bureau of Economic Research.

[Journal of Law and Economics, vol. 57 (November 2014)]

(c) 2014 by The University of Chicago. All rights reserved. 0022-2186/2014/5704-0038 $\$ 10.00$ 
Court's lead in Gregory, have fashioned various doctrines "to prevent taxpayers from subverting the legislative purpose of the tax code by engaging in transactions that are fictitious or lack economic reality to reap a tax benefit" (Coltec Industries, Inc. v. United States, 454 F.3d 1340, 1353-54 [Fed. Cir. 2007]). These judicial doctrines include the economic substance test applied in Coltec (to evaluate whether a transaction has a nontax economic benefit), the substance-over-form test (to evaluate the true nature of a transaction), the step-transaction test (to collapse a series of interrelated or dependent transaction steps), and the shamtransaction test (to challenge transactions that exist only on paper). All are based on the premise that "the simple expedient of drawing up papers" will not control the tax treatment of a transaction if the objective economic realities do not comport with the form in which the deal has been cast (Commissioner v. Tower, 327 U.S. 280, $291[1946]){ }^{1}$

In recent years a large amount of litigation has focused on tax shelters that the Internal Revenue Service (IRS) has deemed abusive. An abusive tax shelter is generally understood as a scheme that attempts to reduce tax without changing the value of the user's income or assets. ${ }^{2}$ As a result in part of increased earnings and wealth from a robust economy, tax shelters became quite prevalent in the late 1990s and early 2000s. ${ }^{3}$ By 2006, as more and more tax shelter cases reached the courts of appeal, decisions issued by the various circuits (including the Fourth Circuit in Black \& Decker Corp. v. United States, 436 F.3d 431, 442-43 [4th Cir. 2006], a case discussed in more detail below) coalesced around two common elements: first, that a tax shelter has to have economic substance to qualify for favor-

\footnotetext{
${ }^{1}$ To illustrate, suppose a taxpayer engages in a transaction that on its face involves a debt that must be repaid with interest. While section 163(a) of the Internal Revenue Code states that " $\mathrm{t}]$ here shall be allowed as a deduction all interest paid or accrued within the taxable year on indebtedness," a court in a dispute over the propriety of that deduction may look beyond the statute to determine whether the underlying debt is one to which section 163 speaks. See, for example, Knetsch $v$. United States (364 U.S. 361, 366 [1960]), in which an interest deduction was disallowed to a taxpayer who paid a fee for the "façade of loans" that served no purpose other than the creation of a tax deduction, and BBßT Corp. v. United States (523 F.3d 461 [4th Cir. 2008]), in which a deduction was denied for interest purportedly paid on borrowed funds that were unavailable for the taxpayer's use and were immediately deposited back with the lender.

${ }^{2}$ To quote from a 2003 report by the Government Accountability Office (GAO 2003, p. 6): “Abusive [tax] shelters are complex transactions that manipulate many parts of the tax code or regulations and are typically buried among 'legitimate' transactions reported on tax returns. Because these transactions are often composed of many pieces located in several parts of a complex tax return, they are essentially hidden from plain sight, which contributes to the difficulty of determining the scope of the abusive shelter problem. Often lacking economic substance or a business purpose other than generating tax benefits, abusive shelters are promoted by some tax professionals, often in confidence, for significant fees, sometimes with the participation of tax-indifferent parties, such as foreign or tax-exempt entities. They may involve unnecessary steps and flow-through entities, such as partnerships, which make detection of these transactions more difficult."

${ }^{3}$ According to GAO (2003), tax shelters provided by accounting firms or external auditors potentially siphoned an aggregate $\$ 129$ billion in revenue from U.S. coffers over the period from 1998 to 2003. This includes, for example, an estimated $\$ 4$ billion associated with listed transactions (transactions that the Internal Revenue Service [IRS] has identified as abusive) employed by 99 Fortune 500 companies. For listed transactions, see U.S. Department of the Treasury, Recognized Abusive and Listed Transactions (http://www.irs.gov/Businesses/Corporations/Listed-Transactions---LB\&ITier-I-Issues).
} 
able tax treatment and, second, that economic substance means that, viewed objectively, the transaction could reasonably be expected, ex ante, to achieve some nontax benefit. ${ }^{4}$

Traditionally, some sort of discounted cash-flow analysis has been used to assess the economic substance of tax shelters and other complex transactions. Such an analysis compares the incremental risk-adjusted benefits of the activities with the incremental risk-adjusted costs, ignoring taxes. If benefits exceed costs, the transaction has economic substance. Cash-flow analyses are based on principles of corporate finance that are widely accepted in both business and academic settings. However, a serious shortcoming of such analyses is that they can be very sensitive to long-term financial projections and estimates of discount rates that are developed in the context of litigation, sometimes many years after the fact. ${ }^{5}$

In this paper we put forward an argument-consistent with those made in recent court cases-that additional principles of economics and corporate finance, based on the modern theory of the firm, can be helpful in assessing the economic substance of tax shelters involving corporate reorganizations. According to the property rights theory of the firm, a key difference between an arm's-length transaction and a transaction inside an organization concerns who has residual control rights - that is, who has the right to determine what happens in events not covered by explicit contractual terms. The possession of residual control rights can have important efficiency consequences in a world where contracts are incomplete. Among other things, to motivate individuals it may not be enough to offer them high-powered incentives; it may be necessary also to allocate them ownership or residual control rights.

In many transactions leading to the creation or reorganization of corporate entities, no meaningful transfer of residual control rights actually occurs. These transactions are structured in such a way that both before and after the transaction the company initiating the transaction has complete control. This suggests that the same benefits could have been achieved in-house: that is, such reorganizations or creations of a new entity served no nontax business purpose, lack economic substance, and should not be respected for tax purposes.

The purpose of this paper is to spell out these arguments in more detail. We begin in Section 2 with a summary of the property rights theory of the firm and explain how it applies to corporate reorganizations. In Section 3 we provide a brief overview of contingent-liability tax shelters involving corporate transactions or reorganizations that, on the basis of taxpayer claims, entitle the taxpayer to what amounts to a double deduction on certain anticipated expenses. In Sections 4 and

\footnotetext{
${ }^{4}$ In 2010, Congress codified an economic substance test and clarified certain questions that were not uniformly addressed by the judicial formulations. The new legislation provides that "in the case of any transaction to which the economic substance doctrine is relevant, such transaction shall be treated as having economic substance only if (A) the transaction changes in a meaningful way (apart from Federal income tax effects) the taxpayer's economic position, and (B) the taxpayer has a substantial purpose (apart from Federal income tax effects) for entering into such transaction" (26 U.S.C. sec. 7701[o][1]).

${ }^{5}$ Discounted cash-flow models can also be manipulated. See Aswath Damodaran, What Is Valuation? (http://pages.stern.nyu.edu/ adamodar/New_Home_Page/background/valintro.htm).
} 
5 we apply the property rights theory of the firm to two unrelated contingentliability tax shelter cases that were litigated in federal court: Black \& Decker Corp. $v$. United States and WFC Holdings Corp. v. United States. In Section 6 we discuss how the analysis from those cases can be extended to other sorts of corporate transactions and tax shelters. Conclusions follow in Section 7.

We should emphasize that the change-in-control criterion put forward in this paper for analyzing the economic substance of corporate transactions will not always be dispositive. There will be some situations, such as those described below, where we believe that the absence of a change in control is sufficient to show absence of economic substance. But there will be other situations in which control does change and additional considerations, such as whether the transaction has positive net present value, will be probative. In other words, we see the changein-control criterion as a complement to, rather than a substitute for, current approaches. We return to this point in Section 7.

Another important qualification of our analysis should be emphasized. Throughout the paper we take the tax laws and the economic substance criterion as given. In particular, we suppose that the tax laws are socially desirable and should be followed and that a transaction should be tax favored if and only if it is efficiency enhancing absent its tax consequences. The broader questions of what is an optimal tax law and whether economic substance is an appropriate criterion are very important, but they lie outside the scope of this paper.

\section{A Review of the Property Rights Theory of the Firm}

\subsection{The Basic Approach}

The question of why some transactions take place in firms and others take place through the market was first raised by Ronald Coase in his famous 1937 article (Coase 1937). Since that time, progress on the question has been made by Williamson $(1975,1985)$ and Klein, Crawford, and Alchian (1978), among others. For our purposes, a more recent strand of the literature called property rights theory (PRT) will be helpful, and we begin by reviewing it here. ${ }^{6}$ Property rights theory shares several features with Coase's, Williamson's, and Klein, Crawford, and Alchian's transaction cost economics (TCE), but there are also some important differences.

Like TCE, PRT takes the view that firms arise when parties are engaged in longterm relationships and make relationship-specific investments. A useful example is an electricity plant that locates next to a coal mine (see, for example, Joskow 1985). Ex ante there may be many mines next to which the plant could locate, but

\footnotetext{
${ }^{6}$ Property rights theory (PRT) is developed and discussed in detail in Grossman and Hart (1986), Hart and Moore (1990), and Hart (1995, 1989). For recent extensions of PRT, see Hart and Moore (2008), Hart (2008, 2009), and Hart and Holmstrom (2010). For appraisals of PRT, see Holmstrom and Roberts (1998), Whinston (2003), Aghion and Holden (2011), and Aghion et al. (2014). For empirical work consistent with the theory, see Acemoglu et al. (2010), Baker and Hubbard (2003, 2004), and Kaplan and Stromberg (2003). For a survey of empirical work on transaction cost economics and PRT, see Lafontaine and Slade (2007).
} 
ex post, after its location decision, the plant has little flexibility about its source of coal.

In an ideal world, the parties would govern a relationship like this via a longterm contract. The contract would state what each party's obligations are in all contingencies during the course of the relationship. In practice, it is very difficult to write a comprehensive long-term contract for several reasons, one of which is the difficulty of predicting the future. Instead, parties write contracts that are incomplete. Incomplete contracts specify some obligations of the parties and some contingencies but not others. They are vague and ambiguous in places. They tend to be short-term rather than long-term. They will be renegotiated as time passes and the parties respond to new events.

Lawyers and judges are, of course, extremely familiar with the concept of contractual incompleteness and the role of the courts in completing an incomplete contract. What has been less appreciated in the legal literature, and, until recently, in the economics literature, is that there is another important and very familiar mechanism for completing incomplete contracts. This mechanism involves asset ownership and firm boundaries, and it lies at the heart of PRT.

Property rights theory takes the view that the owner of an asset or a set of assets, such as a firm, has the ability to fill in certain aspects of an incomplete contract. Specifically, the owner of an asset has residual rights of control-that is, the right to decide all uses of the asset not specified in an initial contract (as long as these uses are consistent with the law). In practice, owners often do not exercise residual control rights themselves-they delegate them to a board of directors. This is not important for the basic theory, however, and in what follows, we use the terms "owner" and "board" interchangeably. We do, however, make a distinction between the case in which the person managing an asset or set of assets owns or controls these assets himself and the case where he does not-that is, where he runs a division or subdivision and is answerable to an owner or a board.

To see why the allocation of residual control rights matters, consider the electricity plant and the coal mine, and suppose initially that they are separately owned. Assume that the electricity company needs the coal it burns to be pure but that it is hard to specify in advance what pure coal is because there are many potential impurities. Imagine that ash content is the relevant impurity, and suppose that high-ash-content coal is more expensive for the electricity company to burn but is cheaper for the coal mine to produce. Given that the contract does not specify purity in sufficient detail, the coal mine may be within its rights to supply cheap high-ash-content coal (in effect, it exercises its residual control rights over the characteristics of the coal supplied). The coal mine may be willing to renegotiate the contract and supply low-ash-content coal, but only if it receives a much higher price. As a result, even with a long-term contract, the electricity company is vulnerable and may lose money. Anticipating problems like this over the course of the relationship, the electricity company may find it unprofitable to locate next to the coal mine. ${ }^{7}$

${ }^{7}$ One way to solve this holdup problem is for the parties to specify in their initial contract that the 
Now consider the case in which the electricity company buys the coal mine before locating next to it. If the coal mine manager is thinking of mining high-ashcontent coal, the electricity company can intervene directly to forbid this action. Since the electricity company manager owns or is in charge of the coal mine, it can direct from which part of the mine the coal is taken. Moreover, if for some reason the coal company manager refuses to follow the electricity company's instructions, the electricity company can fire him and replace him with a betterbehaved manager-something that was not possible when they were separate companies.

Possessing residual control rights over the coal mine thus makes the electricity company less vulnerable and encourages it to locate next to the coal mine. However, there is a downside. The electricity company's ability to intervene in the coal mine's operations makes the coal manager more vulnerable. Suppose that the coal manager has an idea about how to mine the coal more efficiently. When the coal mine was separate, this idea would have led to higher profits for the coal mine, and if the manager owned the mine, these would have ended up in the coal manager's pocket. Now that the electricity company owns the coal mine, however, the electricity company may be able to implement the idea without rewarding the manager adequately. Suppose that the electricity company promises the coal manager a fraction of the cost savings he brings about. Costs are notoriously difficult to measure, and the electricity company may be able to use its residual control rights to manipulate these; for example, the electricity company could charge some of its expenses to the coal mine. ${ }^{8}$ Another possibility is that the electricity company may decide not to implement the manager's idea at all..$^{9}$ It could be that the idea has a marginal effect on profit and its principal benefit is that, if successful, it would enhance the coal manager's reputation and career prospects, which is not something that the electricity company cares about. Anticipating that he will not be rewarded for his ideas, either because he will not be compensated financially or because the ideas will not be implemented, the coal manager has less incentive to work hard to identify and implement cost savings when the coal mine belongs to the electricity company than when it is independent.

In summary, there is a trade-off concerning ownership of the coal mine. If the electricity company owns the coal mine, then the electricity company will have strong incentives to invest in the relationship-namely, to locate its plant next to the coal mine-but the coal mine manager will have weak incentives to identify

electricity company must locate next to the coal mine in return for an upfront payment. This works if the location decision is perfectly contractible. However, even if this is the case, other similar investment decisions-such as whether the electricity company should install a boiler that burns this particular mine's coal efficiently-are likely not to be contractible. We discuss the location decision for simplicity.

${ }^{8}$ For discussions of the ability of people to manipulate budgetary or accounting data in order to subvert incentive arrangements, see Lev (2003) and Jensen (2001). It is well known that cost manipulation and questionable accounting practices are hazards in, for example, the movie industry; see Bibicoff (1991) and Caves (2003).

${ }^{9}$ For a discussion of how the allocation of control or authority affects the incentive to have and implement ideas, see Aghion and Tirole (1997). 
cost savings. On the other hand, if the coal mine is independently owned, then the electricity company will have weak incentives to invest in the relationship, but the coal mine manager will have strong incentives to identify cost savings. ${ }^{10}$ This trade-off is central to understanding how ownership structure can affect substantive economic outcomes, according to PRT.

It is worth reemphasizing the three key features of PRT: incomplete contracts, residual control rights, and assets. Contractual incompleteness is important because, in its absence, parties could regulate their relationship entirely via a longterm contract, so ownership and firm boundaries would not matter. Residual control rights are important because they tell us how incomplete contracts get completed via the allocation of ownership. Finally, assets-more precisely, physical or nonhuman assets-are important because it is with respect to these that residual control rights are exercised.

\subsection{Understanding Why Firms Reorganize}

The approach described above can shed light on why the boundary between firms and contracts (or markets) matters. The approach can also help us understand why firms restructure in response to changes in external events.

Various types of restructuring have become common over the last 30 years and have arguably produced large increases in value. These include leveraged buyouts (LBOs), management buyouts (MBOs), corporate spin-offs, and equity carve outs. The success of these organizational forms can be understood using the theory of the firm, and PRT can also explain why the creation of a new business enterprise or a new organizational structure is necessary for the generation of value in these cases.

In an LBO or MBO, a company or division is taken private by either management or another group. These transactions involve the heavy use of debt to purchase the ownership of the entity from its public shareholders or from its parent company. The transactions are characterized by increased management ownership, increased pay for performance, the addition of large, active investors to the board of directors, and the loss of access to public equity markets. The transactions are common in companies and industries that are growing slowly and are generating substantial amounts of cash, much of which is wasted on inefficient investments.

In a spin-off, a publicly traded company distributes some of its assets and liabilities to a newly formed company, and the equity in that company is distributed to the shareholders of the parent company. Each corporation, including the original but now smaller parent, is a separate public company, and, in contrast to an $\mathrm{LBO}$ or $\mathrm{MBO}$, most of the ownership rights remain with public shareholders. Equity carve outs are similar to spin-offs, except that, instead of distributing shares

\footnotetext{
${ }^{10}$ The version of PRT described here emphasizes noncontractible relationship-specific investments as the determinants of organizational form. A more recent element of PRT emphasizes other factors. See, for example, Hart (2009) and Hart and Holmstrom (2010).
} 
to the public, the parent sells a portion to the public and often retains a majority or controlling interest in the carved-out entity.

It is not hard to see why an LBO or MBO structure is conducive to efficiency gains. The combination of pay-for-performance incentives, high levels of debt, and significant managerial ownership means that good performance is highly rewarded while bad performance is heavily penalized. In other words, incentives are high powered. This is very different from the situation that many managers face in large corporations, where the relationship between pay and performance is relatively weak.

An important question is, why is it not possible to duplicate the high-powered incentives of an LBO or MBO while staying within the confines of the original corporate entity - that is, without a corporate restructuring? We do, after all, see the use of incentive schemes in companies. Consider a company that is planning to sell a division to private investors via an $\mathrm{LBO}$ or MBO. Why can the company not generate the same efficiencies in the following manner: retain the managers as employees and put them on an explicit incentive scheme, whereby they receive very large bonuses if divisional profit is high and low salaries or even dismissal if divisional profit is low?

Property rights theory explains why a restructuring is necessary to generate value. The LBO or MBO entity and the original company have completely different control structures. A division inside a large company is not controlled by the people working in the division. Control is held by headquarters (the chief executive officer [CEO] or board of directors of the parent). This creates problems in sustaining high-powered pay-for-performance incentives, just as in the electricity-coal example discussed earlier. Suppose that headquarters tries to create strong incentives inside the large company by writing a contract promising the divisional manager a large bonus if his division does well. The problem is that divisional profits are not well defined because costs are fungible. In particular, what is to stop headquarters from manipulating divisional profit after the fact-for instance, by charging extraneous expenses to the division-thus making divisional profit look smaller than it really is? To the extent that the divisional manager anticipates this, the behavior by headquarters is self-defeating since it will reduce the divisional manager's incentives to generate high profit. However, self-defeating behavior may be hard to avoid: there may simply be no credible way for headquarters to commit ahead of time not to behave opportunistically.

All this changes after an LBO or MBO. Now those whose actions most affect the profitability of the enterprise-top managers and a few key outsiders-collectively own the (former) division, in the sense that they hold both the claims to divisional profits and the (residual) control rights. Nobody can intervene to manipulate the profits of the entity. Nobody can turn down their ideas. Nobody can tell them what to do or fire them. Their incentives to generate an efficient outcome are therefore quite different and far greater.

Spin-offs and equity carve outs are similar in a number of ways to LBOs or 
MBOs, but there are also important differences. The main difference is that control does not shift as clearly as in an LBO or MBO.

In a spin-off, most of the ownership rights remain with public shareholders. However, there are two important changes that occur when a company is spun off. First, a layer of supervision or authority is removed from above the top unit managers. Previously, the top managers had a boss, the CEO of the parent company. This boss could turn down some of their ideas and veto some of their decisions. Now the only group to which they are answerable (apart from public shareholders) is the board of the spun-off company, and top managers are likely to have had considerable influence over the choice of this board. To a large extent, the unit's managers are masters of their own fate.

Second, the profits of the spun-off company have integrity in a way that the profits of a division of the parent did not. Once a unit is independent, an external group cannot siphon profits out of it by forcing it to engage in disadvantageous side deals or by assigning expenses to it. As a separate legal entity, the spun-off unit can veto such transactions. The integrity of profits has two benefits. First, profit-based performance schemes become possible and credible. Second, a public market in the spun-off company's shares can function, and this market will provide important information about the spun-off company's prospects. This in turn can allow for better incentive-based performance compensation for managers (in the form of, for example, equity-based compensation) (see, for example, Holmstrom and Tirole 1993).

As described above, in equity carve outs, the parent often retains a majority or controlling interest in the carved-out entity. At first sight, it may seem that such a restructuring should have no effect on performance. After all, according to PRT, a restructuring matters only if control shifts, and here control remains with the parent. However, a subtle change does occur. Since the board of directors of the carved-out entity owes a fiduciary duty to all shareholders, the parent is limited in its ability to siphon profit out of the entity or to engage in disadvantageous side deals to benefit the parent. If it did so, it would open itself up to breach-offiduciary-duty suits from minority shareholders. This gives the carved-out entity's profit some integrity and provides some role for performance-based compensation, such as stock options. Of course, the parent probably still has some ability to manipulate profit and can intervene in other ways-namely, through its majority board representation. Given that the new entity has limited independence, we would expect an equity carve out to have a less powerful impact on managerial incentives than would a spin-off. And we would expect both to have a less powerful impact than an $\mathrm{LBO}$ or $\mathrm{MBO}$, given that insiders typically have a small ownership stake in a spin-off or equity carve out but a large ownership stake in an LBO or MBO; that is, their incentives in the latter are much higher powered.

We summarize the discussion of this section as follows. Restructurings create value because things are possible in the restructured entity that were not possible before. Specifically, the management of the restructured entity becomes more independent, and the profits earned by the new entity have greater integrity-they 
are less fungible and more transparent. It may even be possible to create a market in the new entity's shares. As a result, management can be motivated in new ways. This effect is most powerful in the case of LBOs and MBOs, but the effect, although muted, is still present in the case of spin-offs and equity carve outs.

\section{Contingent-Liability Tax Shelters}

Contingent-liability tax shelters are corporate transactions that purport to shift the responsibility for managing future expenses (such as environmental cleanup costs, estimated medical costs of employees and retirees, or anticipated payouts from product-liability or other unliquidated claims) to a separate subsidiary. They involve two critical steps. The first step consists of transferring the responsibility for the future (that is, contingent) liabilities to a subsidiary, along with liquid assets valued just in excess of the anticipated cost of the transferred expenses. In the second step, the taxpayer parent sells equity shares acquired from the subsidiary as part of the first step to a third-party investor, which results in a paper loss equal to the anticipated cost of the transferred liabilities.

The tax benefits can be illustrated by way of example. Consider a corporate parent that transfers $\$ 100$ of liquid assets along with the contingent liabilities, which have an expected cost of $\$ 95$, in exchange for equity shares in a new subsidiary. The actual market value of the acquired equity is $\$ 5$. For reasons described in further detail below, the contingent liabilities are ignored for tax purposes. Accordingly, for tax treatment purposes, the value of the acquired shares is $\$ 100$. The contingent liabilities do not get any special treatment in the second step (of which they are not directly part). Thus, continuing with the example, when the parent sells the shares for their fair market value in the second step, it realizes a tax loss-but not a true economic loss-of $\$ 95$ ( $\$ 5$ sales price minus $\$ 100$ cost basis of the shares). In addition, the subsidiary is able to deduct the payments it makes to satisfy the contingent liability it assumed from the parent (who would have otherwise continued to deduct those liabilities in the ordinary course). Because the transaction is structured in a way that allows the parent and subsidiary to file consolidated tax returns, the combined entity realizes two sets of deductions stemming from the contingent liabilities.

The illustrative series of transactions generating this double deduction is depicted in Figure 1. Note, importantly, that the second step of this example would not trigger a tax loss if the contingent liabilities were not ignored in the first step. That is, the cost basis of the shares acquired in step 1 would be the same as the market value, $\$ 5$, and a sale for that amount to the third party in step 2 would not generate any taxable gain or loss.

Contingent-liability tax shelters can be traced to an IRS revenue ruling issued in 1995 (Revenue Ruling 95-74, 1995-2 C.B. 36) that addressed the statutory rules that apply to the transfer of an entire business (or all of the assets and liabilities of a business division) to a subsidiary in exchange for stock. The IRS assumed that the transfer qualified as a tax-free exchange under section 351 of the Inter- 
Step 1: Reorganization Step

Step 2: Third Party Transaction

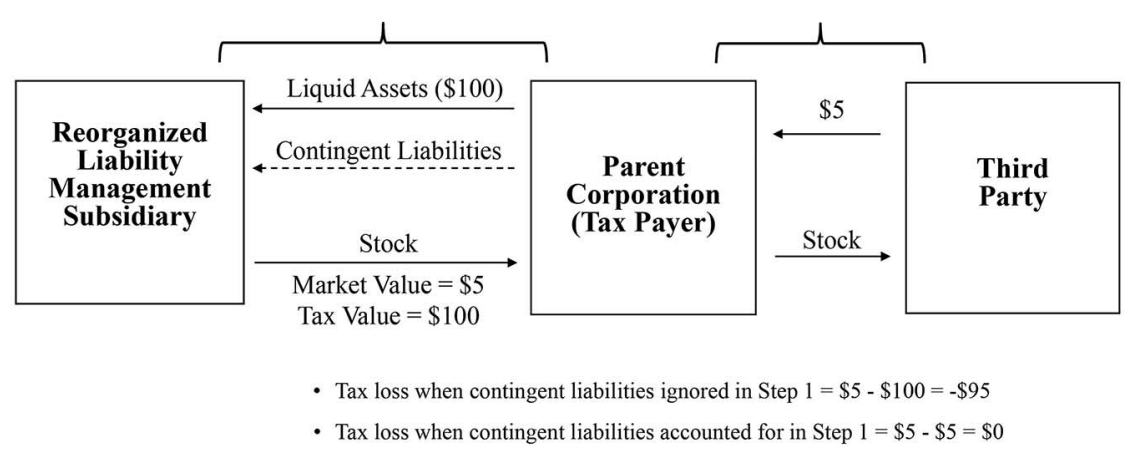

Figure 1. Illustrative depiction of contingent-liabilities transactions

nal Revenue Code. ${ }^{11}$ It then endeavored to answer two questions: What is the tax basis (that is, the amount by which gain or loss from the sale of property is measured) of the stock the parent corporation received in the deal? Can the subsidiary deduct as a business expense the contingent liabilities it assumed as they are paid? To understand the implications of the answers the IRS provided, one must first be introduced to the tax law the ruling interprets.

Ordinarily, the basis of stock a taxpayer receives in a section 351 exchange is the same as the basis of the property the taxpayer transfers, reduced by the amount of liabilities assumed by the other party to the exchange (see I.R.C. sec. $358[\mathrm{a}],[\mathrm{d}][1])$. But in some cases, there is an exception that does not require the taxpayer to reduce its stock basis by the amount of the liabilities (see I.R.C. sec. 358[d][2]). In its revenue ruling, the IRS determined that the taxpayer's basis in the stock of the new corporation is not reduced by the amount of the liabilities the new corporation assumed if the exchange was made for business purposes and involved substantially all of the assets of a going concern. With that question answered, the IRS turned to the effect of the transfer on the new corporation and concluded that since the taxpayer had yet to incur (or deduct) the contingent liabilities, the payment of those liabilities could be deducted as business expenses by the new corporation.

Revenue Ruling 95-74 clearly states that it is limited to the transfer of substantially all of the assets of a going concern for bona fide business purposes. That limitation did not dissuade promoters of aggressive tax strategies from devising

\footnotetext{
${ }^{11}$ Section 351 provides that no gain or loss shall be recognized if property is transferred to a corporation solely in exchange for stock so long as the transferor(s) control the corporation immediately after the exchange. The purpose of the provision is to save the transferor from the immediate recognition of gain (or loss) on the transfer of appreciated (or depreciated) business property for corporate stock. It recognizes that such an exchange is not a sale of the property but a "mere change in the form of ownership" and that "the taxpayer has not really 'cashed in' on a theoretical gain, or 'closed out' a losing venture" (Portland Oil Co. v. Comm'r of Internal Revenue, 109 F.2d 479, 488 [1st Cir. 1940], cert. denied, 310 U.S. 650 [1940]).
} 
and marketing a much broader version of the ruling's hypothetical transaction for taxpayers who had large taxable gains and (importantly) contingent liabilities to shelter them. To quote from a presentation by Deloitte and Touche:

With proper planning and structuring of a series of transactions, a taxpayer may be able to significantly accelerate the deduction (in the form of a capital loss) of such contingent costs. Such planning involves the use of a risk management company or a health care management company and the sale of some of the stock of the company to a third party manager, consultant or investor. With this approach, the taxpayer may be able to deduct a capital loss equal to the amount of the contingency. In addition, the management company may later be entitled to a second deduction for the same amount over time as the expenditures are actually incurred. ${ }^{12}$

In response to the proliferation of transactions that sought to exploit the revenue ruling, the IRS in 2001 issued Notice 2001-17 (U.S. Department of the Treasury 2001) to alert taxpayers that the IRS intended to challenge tax losses produced by those transactions on economic substance (and other) grounds. ${ }^{13}$

\section{Black \& Decker Corp. v. United States}

Despite the issuance of Notice 2001-17, companies went to court to challenge the IRS's disallowance of the tax benefits claimed from step 2 of their contingentliability transactions. One of those cases was filed by Black \& Decker Corporation, which, in 1998, stood to realize a substantial capital gain from the sale of several business divisions. ${ }^{14}$ Like most companies, it also faced growing and uncertain expenses associated with its (self-insured) provision of employee and retiree health benefits. An actuary hired in connection with the contingent-liability transaction concluded that the risk-adjusted net present value of the health care liabilities Black \& Decker would incur from 1998 through 2007 was approximately \$560 million. As a result, it was a prime candidate to engage in a contingent-liability tax shelter.

\subsection{Background and Key Elements of the Black \& Decker HealthCare Management, Inc., Transaction}

In late 1998, Black \& Decker outsourced its employee and retiree health care benefits plans to a dormant subsidiary, renamed Black \& Decker HealthCare Management, Inc. (BDHMI), by contributing \$561 million cash and its contingent health care liabilities to that company in exchange for preferred stock. Black \& Decker HealthCare Management, Inc., was a purported joint venture responsi-

${ }^{12}$ Accelerating Contingent Liability Deductions, exhibit 2, Black \& Decker Corp. v. United States, Civil Action No. 02-2070, Docket No. 71 (D. Md.).

${ }^{13}$ The IRS was aided by the addition of section 358(h) to the Internal Revenue Code. That section requires the tax basis of equity shares acquired in step 1 to be reduced by the amount of any contingent liabilities transferred to the subsidiary (unless the transfer was like the one described in Revenue Ruling 95-74). That statutory fix applied only to transactions after October 18, 1999.

${ }^{14}$ Unless otherwise noted, the facts from this section are drawn from Revised Joint Pretrial Order, Black \& Decker Corp. v. United States, Civil Action No. 02-2070, Docket No. 174 (D. Md.). 
ble for managing the health care liabilities it assumed. The individuals managing the company's health care expenses remained largely the same; in particular, a key manager continued in place. However, their efforts were also assisted by a retired company executive, with relationships and prior management experience throughout the company, who was put on the board of the new entity.

Once the outsourcing was complete, the company executive purchased the BDHMI preferred stock from Black \& Decker for $\$ 1$ million (the difference between the $\$ 561$ million in cash given to the subsidiary and the $\$ 560$ million in assumed liabilities). His compensation was established by a contractual formula that purported to measure changes to the preferred stock's value resulting from BDHMI's efforts to reduce Black \& Decker's health care costs. To help achieve those savings, BDHMI partnered with an outside benefits consultant-the same consultant used by Black \& Decker-whose sister company also owned preferred shares with a value that was based on a contractually determined formula. The BDHMI board of directors consisted of six representatives of Black \& Decker, the retired company executive, and a representative of the sister corporation. The key manager, who managed health care expenses at Black \& Decker before the creation of BDHMI, became chairman of BDHMI, but he remained an employee of Black \& Decker.

As the discussion above suggests, BDHMI was designed to yield significant tax benefits. The primary benefit was an artificial capital loss from the sale of BDHMI preferred stock to the company executive. The amount of that deduction was equal to the present value of the contingent liabilities transferred to BDHMI, and in effect it represented an acceleration of the deductions Black \& Decker would have claimed as ordinary and necessary business expenses as the liabilities were paid. The secondary benefit was BDHMI's ability to continue to deduct as business expenses the health care liabilities it assumed. In other words, just as the promoters of contingent-liability tax shelters had envisioned, Black \& Decker asserted that it was entitled to what amounted to a double deduction associated with its future employee health care expenses. The IRS disagreed, and the dispute ended up in court, where the determination ultimately rested on whether or not the BDHMI transaction had economic substance. ${ }^{15}$

\subsection{Analyzing the Transaction}

What does the theory of the firm tell us about the economic substance of the Black \& Decker-BDHMI transaction? Before 1999, Black \& Decker employed personnel in the human resources department-in combination with outside consultants such as the benefits consultant and independent contractors such as the processor to design and administer its health benefits program. After the

\footnotetext{
${ }^{15}$ The issue of economic substance came front and center only after the district court rejected the United States' statutory argument that Black \& Decker was required to reduce the tax basis of the Black \& Decker HealthCare Management, Inc., (BDHMI) stock it sold to the company executive by the amount of the contingent liabilities BDHMI assumed. See Black \& Decker Corp. v. United States, 2004 WL 2051215 (D. Md. August 3, 2004).
} 
Black \& Decker-BDHMI transaction, health care benefits were administered by a new entity, BDHMI, again in combination with the benefits consultant and the processor. The key manager remained the same. The company executive was brought in as a board member and was compensated on the basis of the difference between actual health care expenses as they transpired and the contemporaneous baseline projections. Can one argue that these organizational shifts made management more independent and allowed the use of higher-powered incentives and that this brought about efficiency gains that could not be achieved internally?

It is certainly true that some things changed. During the period from December 1998 through September 2003, BDHMI suggested, and Black \& Decker thereafter implemented, a number of proposals for reducing employee and retiree health care plan costs, including the following: encouraging retired employees to convert to health maintenance organizations as their health care providers, outsourcing the administration of the retiree health plan, increasing the portion of health care premiums paid by current and retired employees, increasing active and retired employees' co-payments for health care expenses, increasing active and retired employees' co-payments for prescription drugs, replacing the pointof-service and indemnity plans with a preferred-provider organization (PPO) plan, adopting a three-tier prescription drug co-payment system, creating a dental PPO for employees, adopting a two-tier benefit plan, and instituting a wellness lifestyle program, under which Black \& Decker encouraged smoking cessation, weight loss, and exercise by banning smoking in all of its companies' facilities and vehicles, reimbursing employees for the prescription drug Zyban, offering on-site smoking cessation classes, reimbursing employees for Weight Watchers meeting costs, and subsidizing fitness programs. The central question with regard to Black \& Decker's tax claim is, could these proposals have been implemented just as well without the creation of BDHMI? One approach to answering this question is to ask whether similar changes occurred at other companies that tried to control their health care expenses but did so in-house. However, even if there are examples like this, the argument can always be made that these other firms are different and that Black \& Decker required another approach. Thus, it is also useful to provide a more comprehensive answer. This is where PRT comes in. According to PRT, there is no substantive difference between a transaction inside a firm and between firms unless there is a shift in residual control rights. Thus, the answer to the question whether forming BDHMI created value hinges on whether residual control rights shifted to BDHMI.

A striking feature of the Black \& Decker-BDHMI transaction is that residual control rights did not shift: Black \& Decker maintained complete control over the operations of BDHMI. Specifically, Black \& Decker had the majority of the votes of BDHMI, Black \& Decker could elect the majority of the board members (six out of eight) and could replace them at any time, and all decisions of the BDHMI board had to be ratified by Black \& Decker's senior vice president of human resources.

An implication of this is that the parties working on the provision of health 
care benefits for Black \& Decker employees and retirees have no more independence after the transaction than they had before. Suppose that the key manager or the benefits consultant comes up with an idea for reducing costs. When health care benefits were administered and paid for inside Black \& Decker, this idea would have had to be approved by the senior vice president and ultimately by the Black \& Decker board. Now that BDHMI is a separate entity, this is still the case. First, as we have seen, all decisions of the BDHMI board have to be ratified by the senior vice president. Second, given that Black \& Decker appoints the majority of the BDHMI board and can replace its representatives at any time, it can easily veto any decision that it does not like.

To take another example, suppose that the key manager's performance starts to deteriorate and Black \& Decker wants to replace him as a top manager. This was easy to do when health care benefits were managed in-house. However, it is still easy to do now that BDHMI is a separate entity. Black \& Decker can simply instruct the board to fire him or replace the majority of board members if it refuses to do this.

We noted in Section 2 that there are some restructurings, such as equity carve outs, in which control does not shift and yet there can be real effects on performance. These effects occur because the profits of the new entity have greater transparency and integrity, and this can permit the use of performance-based compensation. Moreover, the benefits of performance-based compensation are increased if greater transparency of profits permits the creation of a public market in the carved-out entity's shares and the market yields important information about the entity's prospects.

It is hard to believe that the greater transparency of profits could have been an important factor in the present context. The key parties able to generate cost savings were the key manager, the company executive, and the benefits consultant (and possibly the sister corporation). The key manager did not have a formal incentive scheme with BDHMI. The benefits consultant was paid on a fee-forservice basis. The company executive and the sister corporation held securities whose return was determined by a formula in which BDHMI profit did not appear directly. Furthermore, the parties specified a mechanism for determining the values of the variables that were in the formula-benefit liabilities plus various positive and negative adjustments-and the ability to manipulate this mechanism was independent of ownership or control rights. Finally, BDHMI does not benefit from participating in public equity markets.

We do not intend to suggest that ownership and control could not have been relevant in the Black \& Decker-BDHMI transaction. For example, Black \& Decker, through its majority board representation, can decide whether to fire the key manager or whether to renew the benefits consultant's contract. If control had shifted to the key manager or the benefits consultant (or the associated sister corporation), such decisions might conceivably have been made differently. This in turn might have affected the key manager's or the benefits consultant's incentives. However, control did not shift-it stayed with Black \& Decker.

In summary, the idea that the Black \& Decker-BDHMI transaction made man- 
agement more independent and allowed the use of higher-powered incentives, and that this yielded efficiency gains, is unconvincing. It is quite possible that health care benefits were not being managed efficiently inside Black \& Decker before 1999 and that some improvements were feasible. In particular, there may have been an excessive focus on reducing short-term costs at the expense of generating long-term cost savings. However, given that there was no change in control, these improvements could have been achieved simply by changing the incentive arrangements between Black \& Decker and its employees and outside contractors rather than through the creation of a new business entity. Moreover, doing things this way would have saved substantial transaction costs associated with making BDHMI responsible for Black \& Decker's health care liabilities; these costs ultimately amounted to nearly $\$ 3$ million in legal and other fees.

\subsection{Disposition of the Case}

What did the court decide in Black \& Decker? Prior to trial, the district court granted summary judgment in favor of Black \& Decker under the shamtransaction test. The judge's reasoning was that significant business activity took place within BDHMI, and so even if the transaction was tax motivated (which Black \& Decker conceded for summary judgment purposes), it was not a sham. The Fourth Circuit reversed the judgment for Black \& Decker and remanded the case to district court for trial. In doing so, the Fourth Circuit ruled that substantial business activity within BDHMI did not imbue the BDHMI transaction with economic substance. Rather, the BDHMI transaction had to have the potential to realize significant nontax benefits in order for Black \& Decker to claim the tax benefits that the transaction was designed to maximize. On that score, the Fourth Circuit noted that the government had offered ample evidence (from four expert witnesses) to permit a reasonable trier of fact to conclude that Black \& Decker lacked a reasonable expectation of earning a nontax profit from the BDHMI transaction (Black \& Decker, 436 F.3d 442). The case settled soon after, rendering the trial unnecessary.

\section{WFC Holdings Corp. v. United States}

A second contingent-liability tax dispute involved Wells Fargo, a global financial services company. In 1998 Wells Fargo had \$483 million in capital gains. In that same year it transferred contingent liabilities related to real estate leases estimated to be underwater by approximately $\$ 426$ million. ${ }^{16}$ As had Black $\&$ Decker, Wells Fargo asserted that it was entitled to what amounted to a double tax deduction: one in the form of a capital loss from the sale of stock it received in the initial exchange and another in the form of ordinary and necessary business

\footnotetext{
${ }^{16}$ Unless otherwise noted, the facts described in this section are drawn from the district court's findings of fact in WFC Holdings Corp. v. United States (2011 WL 4583817 [D. Minn. 2011], aff'd, 728 F.3d 736 [8th Cir. 2013]) and from the Report of Oliver D. Hart, submitted in WFC Holdings on December 1, 2008 (https://ecf.mnd.uscourts.gov/doc1/10112809711).
} 
expenses associated with the transferred leases. The government, in contrast, asserted that the transaction that produced the capital loss was an economic sham and should be disregarded as such. We will see that the structure of the transaction is quite similar to that in Black \& Decker but that the transaction raises additional issues that PRT can help to resolve.

\subsection{Background and Key Elements of the Transaction}

As of 1998, Wells Fargo, as a result of mergers and office space consolidation, had sublet numerous properties to third parties. Many of these leases were underwater, in the sense that Wells Fargo earned less from its subtenants than it was paying under the original leases.

In December 1998, Wells Fargo transferred securities and approximately two dozen underwater leases to Charter, a dormant subsidiary, under an exchange agreement. The difference between the present value of lease expenses and the present value of sublease income on the underwater leases was estimated to be approximately $\$ 426$ million. The transferred securities were intended to fund the lease liabilities and were nearly equivalent in value (after accounting for nominal stockholder equity payments). Together, the exchanged lease liabilities and securities accounted for virtually all the assets and liabilities of Charter.

As a result of the exchange, Wells Fargo received 100 percent of Charter's common stock and preferred shares. The preferred stock carried a 6.625 percent dividend and was voting, cumulative, and nonparticipating. In addition, if the tax laws on dividends changed, the dividend on the preferred shares would be adjusted so that preferred shareholders received the same amount in net terms as before the tax change. Further, a support agreement between Wells Fargo and Charter essentially guaranteed that Wells Fargo would make up any shortfall if Charter had insufficient funds to make the required dividend payments.

In February 1999, Wells Fargo sold 20 percent of the preferred shares to Lehman Brothers for $\$ 3.75$ million. Thus, at this date, Wells Fargo owned all the common equity and 80 percent of the preferred equity in Charter, and Lehman owned 20 percent of the preferred equity. Each common and preferred share of Charter had one vote. Since Wells Fargo owned 630,000 shares of common stock and 16,000 shares of preferred stock, while Lehman owned 4,000 shares of preferred stock, Wells Fargo had over 99 percent of the votes. Although Wells Fargo required approval from Lehman to take certain actions affecting the rights of preferred shareholders, in all other matters, such as the selection of the board of directors, Wells Fargo had complete control.

As of December 1998, Charter's board of directors had three members. In addition, Charter had two officers. All of these individuals, except for possibly one, were also employees of Wells Fargo. The two senior managers had a formal bonus plan with Charter that involved a formulaic assessment of Charter's performance. These assessments were done annually and on a property-by-property basis. For each property, a benchmark calculation of the net present value (NPV) of the underwater lease liabilities was made based on a December 1998 projection. 
These benchmark calculations were intended to capture the difference between what Charter was paying on the master leases and what it was receiving from subtenants. Charter's annual performance was measured by comparing revised NPV calculations that incorporated actual performance to date, as defined in the executive officer bonus plan, with the 1998 benchmark calculations.

Charter's aggregate performance was calculated as the sum of the gains associated with individual properties in which gains were achieved. That is, properties with measured losses were not included in each year's aggregate performance measurement. According to the bonus plan, as of 2003, the two senior managers were entitled to 6 percent and 4 percent, respectively, of the measured performance gains, as long as certain prespecified thresholds were met. On the basis of $\$ 56.8$ million in calculated performance gains through 2003, the two senior managers were entitled to $\$ 3.4$ million and $\$ 2.3$ million, respectively.

\subsection{Analyzing the Transaction}

What does the theory of the firm tell us about the economic substance underlying the Wells Fargo-Charter transaction? Before December 1998, Wells Fargo employed personnel in its Corporate Properties Group to manage its leases. After December 1998, 21 of these leases were transferred to Charter. The personnel working on the 21 leases remained essentially the same. In addition, Charter's two senior managers had been and continued to be Wells Fargo employees.

The business case prepared by Wells Fargo highlighted two important economic benefits of creating Charter. First, managers would be incentivized to beat the market, and such incentives would likely contribute to the success of the project. Second, transferring the underwater leases to Charter would allow for improved negotiations with (prospective) subtenants that had deposit or borrowing relationships with Wells Fargo and had leveraged (or might leverage) these arrangements to get more favorable leasing terms.

There is a problem with both of these arguments. A striking feature of the Wells Fargo-Charter transaction is that Wells Fargo maintained complete control over the operations of Charter: Wells Fargo had over 99 percent of the votes of Charter and could elect or replace the board of directors at any time. Further, the support agreement between Wells Fargo and Charter required Wells Fargo to maintain enough votes to be able to elect a majority of Charter's board of directors, so Wells Fargo would always remain in control of Charter. An implication of this was that the parties working on the management of leases had no more independence after the transaction than they had before.

Suppose that one of the senior managers comes up with an idea for filling vacant properties-for example, a new marketing plan. When leases were managed by Wells Fargo's Corporate Properties Group, this idea could be vetoed by Wells Fargo top management if it did not fit in with their overall strategy or they thought it was a mistake. This is still the case when the leases are managed by Charter. Given that Wells Fargo appoints the Charter board, it can veto any decision that it does not like. While Charter may be a separate legal entity, the senior 
managers and other Charter employees are no more autonomous from Wells Fargo than they were before. To take another example, suppose that the performance of one of the senior managers starts to deteriorate and Wells Fargo wants to replace him. This was easy to do when leases were managed in-house. However, it is still easy to do when Charter is a separate entity. Wells Fargo can simply instruct the board to fire the senior manager and replace the board if it refuses.

Let us turn to the argument that negotiations with (prospective) subtenants that had deposit or borrowing relationships with Wells Fargo would change with the emergence of Charter. One rationale appears to have been that Wells Fargo bank customers would recognize Charter as distinct from Wells Fargo and no longer attempt to leverage their deposit or borrowing relationship to receive favorable sublease terms. It is hard to make sense of this given that Charter was not an independent entity; Wells Fargo had complete control over its board. Further, the people involved in managing the Charter leases were Wells Fargo personnel. Thus, any client who understood Charter's corporate structure would realize that its ability to persuade Wells Fargo to put pressure on the lease negotiators was exactly the same after the formation of Charter as before. In addition, Wells Fargo continued to present its face to the subtenants of some underwater leases. As of June 30, 1999, no notices of transfer had been sent to the subtenants of 21 underwater leases, and rent checks from subtenants continued to be paid to Wells Fargo. Finally, some of the materials associated with the sublease agreements indicated Wells Fargo's involvement.

A second rationale, provided by Charter's two senior managers, was that the presence of a third party, Lehman, changed Charter's negotiating stance. Charter could and did argue that it was unable to provide special deals for prospective subtenants with Wells Fargo banking relationships, given its obligations and fiduciary duty to Lehman. This claim could make sense if Lehman's returns from its investment in Charter actually depended in a meaningful way on the terms of the leases that Charter signed. However, this was not the case. The returns associated with Lehman's investment in Charter were prespecified and backed both by Charter and by Wells Fargo, through the support agreement mentioned above. Charter's actions as they related to potential good-customer discounts had no practical effect on the combined financial integrity of Charter and Wells Fargo. Thus, the assertion that the discounts that Charter might grant Wells Fargo's bank customers could adversely affect Lehman is unconvincing.

Of course, it may have been the case that prospective subtenants believed that Charter was independent even if it was not or believed that Lehman's investment was at risk even if it was not. In other words, it is possible that clients had wrong perceptions. However, the business purpose of a transaction that relies on subterfuge seems questionable. ${ }^{17}$ An additional argument, made by one of the se-

\footnotetext{
${ }^{17}$ Implicit in both of these rationales is the idea that it is in Wells Fargo's interest that Charter be seen by subtenants as independent so that they cannot leverage their deposit or borrowing relationships to obtain more favorable leasing terms. This is in fact far from obvious. Leverage might allow Wells Fargo to price discriminate, offering better deals to some subtenants (those with deposit or
} 
nior managers and others, is that to improve performance it was important for the leases to be separated from the day-to-day operations of the bank. However, creating a unit inside Wells Fargo whose sole purpose was to manage the leases would have achieved the same goal.

As noted with regard to Black \& Decker, it is hard to believe that the greater transparency of profits could be an important factor in Wells Fargo's case. The compensation of the key parties who might be able to improve the leasing was determined by a formulaic calculation that did not depend on Charter's profit. Furthermore, Charter did not benefit from participating in public equity markets.

In summary, the idea that the Wells Fargo-Charter transaction made management more independent and that this permitted the use of higher-powered incentive schemes, or allowed management to bargain more aggressively with lessees or lessors, is unconvincing. There was no change in independence. It is quite possible that leases were not being efficiently managed inside Wells Fargo before December 1998 and that some improvements were feasible. However, these improvements could have been achieved by changing the incentive arrangements between Wells Fargo and its employees via contract rather than through the creation of a new business entity, Charter. Moreover, doing things this way would likely have saved significant transaction costs, just as in the Black \& Decker transaction. ${ }^{18}$

\subsection{Disposition of the Case}

Following a trial in October 2010, the district court found that Wells Fargo lacked a legitimate business purpose for engaging in its contingent-liability transaction and that the transaction lacked economic substance (which the court considered independently). Specifically, the court found that "Charter ... is a straw entity controlled by WFC and created for the purpose of effectuating the [transaction]. Its nature undermines a finding of a 'genuine multiple-party transaction." In addition, the court asserted that "[b]ringing in Lehman seemed to have no economic value of any kind" and that the 1998 transaction was "simply not [that] of a company that sought to use the presence of an outside investor to deleverage good bank customers." Finally, the court stated, "[A]ny argument for efficiency based on the executive bonus plan is illusory," as Wells Fargo could have implemented such a bonus plan, with lower administrative costs, without the 1998 transaction. (WFC Holdings Corp., 2011 WL 4583817 44).

borrowing relationships) than to others (those without). We do not pursue this issue further but simply note that it casts additional doubt on the merits of the business case.

${ }^{18}$ There is one important additional consideration in the Wells Fargo case. Wells Fargo also had a regulatory motive for setting up Charter. Doing so allowed Wells Fargo to switch regulators from the Office of the Comptroller of the Currency to the Federal Reserve Board, which gave it a longer period of time to dispose of real estate that was owned but not used for banking purposes (namely, other real estate owned). Without going into the question of whether regulatory shopping qualifies as a legitimate business purpose, let us just note that the regulatory benefits could have been achieved without bringing a third party, Lehman, into the transaction. This would surely have saved some legal and other costs. At the same time, without a third party, Wells Fargo would not have qualified for the tax benefits that the court found were at the heart of this transaction. 
Each finding is based on, and consistent with, the PRT principles that were presented to the court. Wells Fargo appealed the ruling, but in 2013 the Eighth Circuit affirmed the district court's decision.

\section{Ownership, Control, and Related Tax Disputes}

The economic substance of ownership is central in many tax disputes, and the PRT framework proves useful in providing guidance beyond the two cases described above. Consider, for example, TIFD III-E, Inc. v. United States, commonly known as Castle Harbour. ${ }^{19}$ In this case the taxpayer argued that it had entered into a partnership with two Dutch banks and that the banks had received an equity stake in the partnership. The taxpayer's argument that the transaction had the bona fide economic substance of raising equity capital rested critically on its assertions that the securities received by the Dutch banks were properly characterized as equity. Both a trial court and an appellate court evaluated the nature of the cash flows associated with the securities as well as the corresponding risks. Consistent with PRT, both courts examined whether the banks had received management or control rights. The trial court, however, sided with the plaintiff and held that even though the Dutch banks had not received any control or management rights, they had nonetheless received equity. The district court reasoned that the "average stockholder of a publically traded corporation has no management rights, but there is little doubt he holds equity" (Castle Harbour, 342 F. Supp. 2d 116). Given that the lack of control rights did not automatically disqualify a security from being equity, the district court found that the securities received by the Dutch banks carried enough uncertainty and equity-like properties to be considered equity.

This superficial observation ignores the role that even those with individually small holdings of shares and votes can have in influencing and constraining managerial decision making. Critically, small shareholders can form voting blocs and coalitions with other similarly situated shareholders or can sell their shares and votes to an activist investor or takeover bidder who will then have enough votes to affect what the company does. This threat constrains the actions of a company's managers. ${ }^{20}$ Further, in the context of public companies, enough dissenting votes can signal significant dissatisfaction and lead managers to reevaluate their strategy. Composition of ownership is critical here: small shareholders have power precisely because there is no large shareholder who can outvote them.

In Castle Harbour, in contrast, the presence of a majority shareholder precluded the minority shareholder from any direct influence on decision making. Even though the Dutch banks contributed nearly 20 percent of the partnership's assets, they were not entitled to any votes and exercised no managerial control or

\footnotetext{
${ }^{19}$ Unless otherwise noted, the facts from this section are drawn from TIFD III-E, Inc., v. United States (Castle Harbour), 342 F. Supp. 2d 94 (D. Conn. 2004), rev'd and remanded, 459 F.3d 220 (2d Cir. 2006), judgment on remand, 660 F. Supp. 2d 367 (D. Conn. 2009), rev'd, 666 F.3d 836 (2d Cir. 2012).

${ }^{20}$ There is a voluminous literature on activist investors and the market for corporate control. For a summary, see Shleifer and Vishny (1997).
} 
influence. The district court found that Federal Aviation Administration rules actively precluded the possibility of giving the Dutch banks a right to elect managers (Castle Harbour, 342 F. Supp. 2d 104, note 26). Even without that limitation, the Dutch banks' securities were, effectively, meaningless in controlling how the company would be run; as a result, they lacked, as PRT highlights, the defining feature of ownership when viewed in terms of economic substance.

Ultimately, the Second Circuit (twice) overturned the district court and found that the "facts and circumstances presented, considered in their totality, compel the conclusion that the Dutch banks' interest was, for tax purposes, not a bona fide equity participation" (Castle Harbour, 459 F.3d 241), relying on an analysis of seven factors that, it decided, suggested that the banks had received debt, not equity. While the Second Circuit generally relied upon the district court's analysis of the cash flows associated with the Dutch banks' securities, it concluded that the risks associated with these securities were not sufficient to warrant their categorization as equity. In short, the Second Circuit determined that while the consideration received by the Dutch banks had some of the superficial appearances of equity, the bulk of the evidence suggested that "the funds were advanced with reasonable expectations of repayment regardless of the success of the venture" (459 F.3d 232, from Gilbert v. Comm'r of Internal Revenue, 248 F.2d 399, 406 [1957]).

The conflicting decisions reached by the courts in Castle Harbour demonstrate the murky nature of characterizing debt and equity on the basis of cash flows and risks. A wide variety of factors drive the underlying risks of the cash-flow rights associated with a given security, and the corresponding risk profiles are challenging to measure. Further, there are many ways to formulate payment terms that are neither uniform and fixed (like those traditionally associated with debt) nor entirely residual (like those associated with equity). Establishing a bright-line distinction between debt and equity in terms of income rights can pose significant challenges and may be open to abuse. ${ }^{21}$ Property rights theory highlights that courts need not undertake such a difficult endeavor because, from an economic substance perspective, control is the defining characteristic of ownership, and control rights are often much easier to identify. ${ }^{22}$

Analysis of another case, Canal Corp. v. Commissioner, highlights a similar observation..$^{23}$ In this case, the taxpayer formed what it characterized as a partnership with another large paper company, Georgia Pacific (GP), in which both firms contributed their tissue paper businesses. The partnership then obtained a loan from an outside bank, which was guaranteed by GP. While GP received 95

\footnotetext{
${ }^{21}$ For instance, see Englebrecht, Chiang, and Wang (2008) and Financial Accounting Standards Board (FASB) (2010), noting that an objective of a recent FASB initiative intended to "improve and simplify the financial reporting requirements for financial instruments with characteristice of equity" was to "[e]liminate more than 60 pieces of current U.S. accounting literature that are inconsistent, subject to structuring, or difficult to understand and apply."

${ }^{22}$ Of course, in practice, income rights and control rights will often be held together, and indeed there are strong economic reasons for this. See, for example, Grossman and Hart (1988) and Harris and Raviv (1988).

${ }^{23}$ Unless otherwise noted, the facts presented in this section are from Canal Corp. v. Comm'r of Internal Revenue, 135 T.C. 199 (2010).
} 
percent of the partnership's equity, the taxpayer received a cash payout from the proceeds of the bank loan for nearly the entire value of the business it contributed.

The regulations under the Internal Revenue Code permit the IRS to recharacterize the contribution of a business to a partnership for cash as a disguised sale that (assuming the cash received exceeds the basis of the property contributed) triggers a taxable gain. After the IRS recharacterized the transaction as a sale, the taxpayer argued that the transaction was actually a debt-financed transfer of consideration that should qualify as an exception to the disguised-sale rule (see, for example, Silverman and Nocjar 2012). This exception exists when a taxpayer transfers a business to a partnership, receives cash, but remains economically liable for some amount of the debt raised by the partnership. In such a case, the amount of the taxpayer's remaining liability can reduce the amount of the taxable gain. In Canal, the taxpayer, through a subsidiary, indemnified the other partner's guarantee of the partnership's debt and argued that this indemnity generated an economic interest in the liabilities of the partnership and greatly reduced its tax burden.

Of note, however, is the fact that the taxpayer had given up all management and control rights to its tissue paper business and does not appear to have been able to influence or constrain managerial decision making through covenants or other mechanisms in the indemnity. Rather, GP took over full control of the operation, apparently leaving the taxpayer with no recourse should GP take some action increasing the risk that the indemnity would be called. This did not expose the taxpayer to any real economic liability under the indemnity, however, because the indemnity (which GP did not request or require) covered only the principal payments on the loan, due in 30 years, and limited GP to the assets of one of the taxpayer's subsidiaries, with no provisions mandating that the subsidiary retain assets to cover the indemnity (Canal, 135 T.C. 212-14). On the basis of this reasoning, the tax court denied the taxpayer's claims and ruled that the transaction was, in fact, a disguised sale.

How does PRT relate to Canal? Property rights theory offers an alternative approach to evaluating the disguised-sale exception. From a PRT perspective, the taxpayer's contribution to the partnership was unambiguously a sale of its paper business because the taxpayer transferred full control of its assets to the partner. That is, the taxpayer retained no authority over how those assets could be used. Similarly as in Castle Harbour, focusing on control provides a clearer standard than one that depends on determining whether a given party's financial risk is, subsequent to the transaction, substantial enough.

These two examples illustrate a general point: evaluating a sale on the basis of control rights can be sufficient and allows the trier of fact to avoid the murkiness associated with establishing a specific cash-flow and risk threshold. Canal demonstrates the complexities of accounting for risk exposure in uncertain business environments over long periods of time and in the face of insurance contracts, indemnification clauses, and inactive corporate subsidiaries. Common approaches to measuring risk are notoriously sensitive to the assumptions on which 
they rely (see Brealey and Myers [2000, pp. 259-68], discussing sensitivity analysis, and Higgins [2009, pp. 103-6]). A cynical view is that a given transaction's terms may be structured to be complex so as to provide the appearance of substantial risk where none exists. Beyond that, since cash flows and risk profiles depend critically on control, evaluating the latter is a more direct route to determining ownership than is evaluating the former.

\section{Conclusions}

The purpose of this paper is to demonstrate how the economics of ownership and control, specifically PRT, can provide guidance in evaluating the appropriate tax treatments associated with complex corporate transactions. Evaluations of economic substance in the context of a corporate transaction often depend on an assessment of whether a particular party's income claims look more like equity or more like debt or on a present-value calculation of the efficiency benefits flowing from the transaction. However, characterizing a party's income rights can be very challenging, and calculations of NPV are notoriously sensitive to assumptions and judgment.

The view advanced here is that there is an alternative approach that the courts can use that is simpler and, importantly, more directly captures the economic substance associated with ownership. According to PRT, the fundamental property of ownership is control. Thus, whether a corporate transaction has economic substance can be determined, at least partly, by evaluating whether the transaction involves a meaningful change in control. Did a key party who did not have control before the transaction gain control? Making such a determination can be relatively straightforward.

We have used the PRT approach to analyze the Black \& Decker and Wells Fargo transactions. In both cases there was no meaningful change in control and so, according to PRT, no economic substance. The district court in Wells Fargo agreed, and while that is the only known decision to rely on PRT to evaluate the merits of a tax-motivated transaction, we have seen that PRT is consistent with, and supports, the decisions in the Castle Harbour and Canal.

But what about cases where there is a change in control? Is this enough for the courts to declare that there is economic substance? The answer is surely no. Consider a company that creates a tax shelter in which control does shift, but the control shift is inefficient: it reduces profit by 50 . If the tax gain is 100 , the company will be prepared to bear the inefficiency if doing so ensures that the economic substance test is passed. Yet this is clearly socially inefficient.

To deal with cases like these, we propose a two-prong test. If there is no change in control, then there is no economic substance. But if there is a change in control, a further investigation should be carried out to determine whether the change in control is efficiency enhancing. Considerations that might be brought into play in this second step include the following: Is the change in control cosmetic, or does it plausibly have real effects? Have other companies made efficiency gains using a similar approach? Are there efficiency gains according to a discounted cash-flow 
analysis? This second step will help to screen out value-destroying transactions like the 50/100 case described above.

We should also emphasize that it is unlikely that companies will relinquish control just to satisfy an economic substance test. The research-both theoretical and empirical-cited in note 6 provides strong support for the idea that control is valuable and that giving it up can expose a company to serious risks. In Black \& Decker and Wells Fargo, giving up control of employee and retiree health benefits on the one hand or real estate operations on the other is not something that either company ever seems to have contemplated.

\section{References}

Acemoglu, Daron, Philippe Aghion, Rachel Griffith, and Fabrizio Zilibotti. 2010. Vertical Integration and Technology: Theory and Evidence. Journal of the European Economic Association 8:2-45.

Aghion, Philippe, Mathias Dewatripont, Patrick Legros, and Luigi Zingales. 2014. Introduction. Journal of Law, Economics, and Organization 30(suppl.):i1-i12.

Aghion, Philippe, and Richard Holden. 2011. Incomplete Contracts and the Theory of the Firm: What Have We Learned over the Past 25 Years? Journal of Economic Perspectives 25(2):181-97.

Aghion, Philippe, and Jean Tirole. 1997. Formal and Real Authority in Organizations. Journal of Political Economy 105:1-29.

Baker, George P., and Thomas Hubbard. 2003. Make v. Buy in Trucking: Asset Ownership, Job Design and Information. American Economic Review 93:551-72.

- 2004. Contractibility and Asset Ownership: On-board Computers and Governance in US Trucking. Quarterly Journal of Economics 119:1443-80.

Bibicoff, Hillary. 1991. Net Profit Participations in the Motion Picture Industry. Loyola Entertainment Law Journal 11:23-65.

Brealey, Richard A., and Stewart C. Myers. 2000. Principles of Corporate Finance. 6th ed. New York: McGraw-Hill Higher Education.

Caves, Richard E. 2003. Contracts between Art and Commerce. Journal of Economic Perspectives 17(2):73-84.

Coase, R. H. 1937. The Nature of the Firm. Economica 4:386-405.

Englebrecht, Ted D., Wei-Chih Chiang, and Ying Wang. 2008. An Empirical Assist for Management in Resolving the Debt versus Equity Dilemma. Journal of Business and Accounting 1:121-37.

Financial Accounting Standards Board. 2010. Project Updates: Financial Instruments with Characteristics of Equity (Formerly Liabilities and Equity)_Joint Project of the FASB and IASB. October 26. http://www.fasb.org/project/fi_with_characteristics_of_equity .shtml.

GAO (General Accounting Office). 2003. Challenges Remain in Combating Abusive Tax Shelters: Statement of Michael Brostek, Director, Tax Issues. GAO-04-104-T. October 21. Washington, D.C.: U.S. General Accounting Office. http://www.gao.gov/products/ GAO-04-104T.

Grossman, Sanford J., and Oliver Hart. 1986. The Costs and Benefits of Ownership: A Theory of Vertical and Lateral Integration. Journal of Political Economy 94:691-719. 
1988. One Share-One Vote and the Market for Corporate Control. Journal of Financial Economics 20:175-202.

Harris, Milton, and Arthur Raviv. 1988. Corporate Governance: Voting Rights and Majority Rules. Journal of Financial Economics 20:203-35.

Hart, Oliver. 1989. An Economist's Perspective on the Theory of the Firm. Columbia Law Review 89:1757-74.

- 1995. Firms, Contracts, and Financial Structure. Oxford: Oxford University Press. 2008. Reference Points and the Theory of the Firm. Economica 75:404-11.

. 2009. Hold-up, Asset Ownership, and Reference Points. Quarterly Journal of Economics 124:267-300.

Hart, Oliver, and Bengt R. Holmstrom. 2010. A Theory of Firm Scope. Quarterly Journal of Economics 125:483-512.

Hart, Oliver, and John Moore. 1990. Property Rights and the Nature of the Firm. Journal of Political Economy 98:1119-58.

- 2008. Contracts as Reference Points. Quarterly Journal of Economics 123:1-48.

Higgins, Robert. 2009. Analysis for Financial Management. 9th ed. New York: McGrawHill/Irwin.

Holmstrom, Bengt, and John Roberts. 1998. The Boundaries of the Firm Revisited. Journal of Economic Perspectives 12(4):73-94.

Holmstrom, Bengt, and Jean Tirole. 1993. Market Liquidity and Performance Monitoring. Journal of Political Economy 101:678-709.

Jensen, Michael C. 2001. Value Maximization, Stakeholder Theory, and the Corporate Objective Function. Journal of Applied Corporate Finance 14(3):8-21.

Joskow, Paul. 1985. Vertical Integration and Long-Term Contracts: The Case of Coal-Burning Electric Generating Plants. Journal of Law, Economics, and Organization 1:33-80.

Kaplan, Steven, and Per Strömberg. 2003. Financial Contracting Theory Meets the Real World: Evidence from Venture Capital Contracts. Review of Economic Studies 70:281316.

Klein, Benjamin, Robert G. Crawford, and Armen A. Alchian. 1978. Vertical Integration, Appropriable Rents, and the Competitive Contracting Process. Journal of Law and Economics 21:297-326.

Lafontaine, Francine, and Margaret Slade. 2007. Vertical Integration and Firm Boundaries: The Evidence. Journal of Economic Literature 45:629-85.

Lev, Baruch. 2003. Corporate Earnings: Facts and Fiction. Journal of Economic Perspectives 17(2):27-50.

Shleifer, Andrei, and Robert W. Vishny. 1997. A Survey of Corporate Governance. Journal of Finance 52:737-83.

Silverman, Mark J., and Aaron P. Nocjar. 2012. Partnership Disguised Sale Rules. Practising Law Institute, Washington, D.C. http://www.steptoe.com/attachment.html/3734/ disgsaleoutline.DOC.

U.S. Department of the Treasury. Internal Revenue Service. 2001. Contingent Liability Tax Shelter: Notice 2001-17. Internal Revenue Bulletin 2001-9:730-31.

Whinston, Michael D. 2003. On the Transaction Cost Determinants of Vertical Integration. Journal of Law, Economics, and Organization 19:1-23.

Williamson, Oliver E. 1975. Markets and Hierarchies: Analysis and Antitrust Implications. New York: Free Press.

. 1985. The Economic Institutions of Capitalism. New York: Free Press. 